\title{
Effects of graphic organizer and animation on students learning outcomes in Mathematics
}

\author{
Oginni, O.I. \\ Department of Science Education, Ekiti State University, Nigeria
}

\begin{abstract}
The study examined the effects of graphic organizer and animation on students learning outcomes in Mathematics. The study employed pretest, post test quasi experimental design. The sample for this study consisted of 227 SSII students using multistage sampling procedure. One local government was randomly selected from the state together with three schools selected randomly with two experimental groups and one control group. Intact classes were used in each of the selected schools. Mathematics Achievement Test (MAT) and Mathematics Attitudinal Questionnaire (MAQ) were the instruments used to collect data for the study. The instruments were validated through the assistant of experts and the reliability coefficient of 0.81 and 0.76 were obtained respectively. The data collected was subjected to descriptive and inferential statistics, all at 0.05 level of significance. The findings revealed that there is significant difference in the learning outcomes of students taught using graphic organizer, animation and conventional strategies. Based on the findings of this study, recommendations were made.
\end{abstract}

Keywords: graphic organizer; animation; multimedia; attitude: performance

\section{INTRODUCTION}

$\mathrm{M}$ athematics is seen as a complex discipline despite several studies and attempts are made to analyze the complexities and the abstract syllogism attached in order to enhance students achievement in the subject. An approach that demonstrates, visualizes, describes and tests the subject matter more clearly and comprehensibly is needed for excellent performance in Mathematics. Researches from various scholars in the field have shown poor performance in the subject; poor method of teaching; inadequate facilities; inadequate teaching and learning materials; attitudinal problems among others. Students' acquisition of knowledge, skills and attitude in Mathematics are much dependent on the teacher's effective teaching. Mathematics teaching suppose to be student centered, these could be achieved by introducing strategies in the area of simulation games, blended learning, interactive boards, multimedia, animation, projections, models, drama, graphic organizer and other teaching and learning process. The choice of graphic organizer and animation strategies in the teaching of Mathematics could help students process and remember content by facilitating the development of Mathematics understanding.

\section{LITERATURE REVIEW}

Graphic organizers rely on visual/spatial reasoning skills more than conventional teaching approaches and may be applied to the teaching of higher-level mathematics. Graphic organizers show relationships and connections between concepts, terms, and facts. According to Owolabi \& Adaramati (2015) graphic organizer has its roots in schema theory, which is a knowledge structure that accompanies or facilitates a mental process. When students learn something new, they must be able to retain the information for later use. Graphic organizers help students process and remember content by facilitating the development of Mathematics and also help meaningful learning in several ways. It is a learning activity that provides the student with an opportunity to organize, summarize, analyze and evaluate different ideas. Thus, it promotes the development of critical thinking skills, which can then be used for other meaningful learning activities (Kumar Manoj \& Rizwaan, 2013)

Creativity and careful attention to detail can be greatly enhanced via the use of visual maps, which is exactly what a graphic organizer is all about. A graphic organizer aids in organizing thought processes as well as creating a framework to collect and compare the information that is being gathered. That is why, in addition to structuring information, organizers can be used to improve students' abilities to comprehend and process that information by seeing it, separated it into categories of what is more important and what less important. Graphic organizers help learners become strategic problem solvers. Graphic organizers can also improve test scores, provided they are used effectively and consistently as an integral part of the problem-solving process in Mathematics.

Critical thinking and higher order thinking skills could be the result of integrating graphic organizer into the teaching of Mathematics. Graphic organizer templates that are useful and effective for teaching and learning process can be acquired from software such as inspiration, kidspiration among others; Studies have shown that effective learning can be assisted through the use of graphic organizer. According to McElory \& Coughlin, (2009) graphic organizer enhanced the critical thinking and higher order thinking skills of the students. According to Pantziara, Gagatsis, and Elia (2009) graphic organizer resulted in the improvement in achievement or performance in the mathematics problem solving. Also Ives, (2007) and Delinda (2007) applied graphic organizer among students with learning disabilities showed that GO helped the students to comprehend the content, organize the information, retain and recall in mathematics as measured by post-tests.

Animations can equally help in mathematics understanding, since they connect abstract concepts to real life objects and 
situations. Students like learning with animations, but using them in education is not effective in every case (Végh \& Stoffová 2017). Students can actively participate in the visualization processes instead of passive observations. The findings of Owolabi \& Oginni (2014) also revealed that there was a significant difference in the performance of students exposed to cartoon style multimedia teaching and those that are conventionally taught. There are different potential uses of animation authoring tools. Mathematics teacher educators can use examples from research or practice to construct a scenario of a classroom or represent students' work on a task. Preservice or inservice teachers can enact lesson planning and instructional skills to construct a scenario of: sample studentteacher dialogue on anticipated work on a task, an introduction of a task, or an explanation of a concept or skill to students. One of the affordances of using animations is being able to create a classroom video (based on research) without the many obstacles that we face when we try to videotape a regular classroom. Taylor, Pountney and Malabar (2007) found out that animated learning materials can prove more useful than static representations for some topics in an experiment conducted with a group of UK undergraduate and animation can potentially be used to support the teaching of mathematical concepts in areas such as rotational symmetry and matrices

Graphic organizer and animation strategies are visual representations or illustrations that depict relationship among the key concepts involved in a lesson, unit or lesson task designed to improve learning outcomes for students, review information, and are especially helpful to students who struggle with arranging information. It is expedient to follow the order or steps in the arrangement of information in Mathematics. Delinda. (2007) adduced that teaching students with learning disability to solve mathematical word problems by using graphic organizer among students showed that it helped the students to comprehend the content, organize the information, retain and recall in mathematics as measured by post-tests. According to Stowe (2015) graphic organizers are an outstanding instructional tool to be used with students of all abilities and grade levels. To increase the effectiveness of graphic organizers, three simple guidelines should be followed: (a) organizers should be clear and straightforward; (b) teachers should teach students how to use organizers and implement them in creative ways; and (c) teachers should integrate them into daily instruction so that students internalize the organizational strategies displayed.

Learning outcomes is a cumulative process of attitude and performance. (Justice, Osei and Daniel 2015). Students' attitude towards mathematics influences the efforts they put in understanding and practicing mathematical concepts and skills. Thus attitudes determine the effort a student is likely to put in his learning of the mathematics. It is therefore necessary for mathematics teachers to strive and sustain positive attitudes towards mathematics for good performance in mathematics.

\section{Purpose of the Study}

This research was done to determine the following;

1. The extent to which the use of graphic organizer and animation treatment will influence the students' leaning outcomes in mathematics

2. To look into the influence of students' gender and location on their learning outcomes in mathematics.

\section{Research Questions}

The following questions were raise to guide the study

1. What are the effects of graphic organizer and animation on the performance of students in Mathematics?

2. What are the effects of graphic organizer and animation on the attitude of students in Mathematics?

\section{Research Hypotheses}

The following null hypotheses were generated and tested at alpha level of 0.05

1. There is no significant difference in the mean score of students in the experimental and control groups prior treatment

2. There is no significant difference in the mean score of students in the experimental and control groups after treatment

3. There is no significant difference in the attitudinal mean score of students in the experimental and control groups before treatment

4. There is no significant difference in the attitudinal mean score of students in the experimental and control groups after treatment

\section{METHODOLOGY}

The study employed pretest, post test quasi experimental design. The population of the study made up of all the senior secondary school students in Osun state. The sample for this study consisted of 227 SSII students using multistage sampling procedure. One local government was randomly selected from the state together with three schools selected randomly with two experimental groups and one control group. Intact classes were used in each of the selected schools. The instruments used for this study are Mathematics Achievement Test (MAT) and Mathematics Attitudinal Questionnaire (MAQ) in order to collect data for the study. The instruments were validated through the assistant of experts and the reliability coefficient of 0.81 and 0.76 were obtained using Pearson's product moment correlation analysis. The data collected were subjected to descriptive statistics of frequency count, mean and standard deviation and inferential statistics of Analysis of Variance (ANOVA) and Scheffe post-hoc analysis where necessary. 


\section{RESULTS}

Research Question 1: What are the effects of graphic organizer and animation on the performance of students in Mathematics?

Table 1: Performance of students before and after exposure to of graphic organizer and animation

\begin{tabular}{|c|c|c|c|c|c|c|c|}
\hline \multirow{2}{*}{ Methods } & \multirow{2}{*}{$\mathrm{N}$} & \multicolumn{2}{|c|}{ Pretest } & \multicolumn{2}{c|}{ Posttest } & \multirow{2}{*}{$\begin{array}{c}\text { Mean } \\
\text { diff }\end{array}$} & $\begin{array}{c}\text { Relative } \\
\text { performa } \\
\text { nce }\end{array}$ \\
\cline { 3 - 7 } & Mean & SD & Mean & SD & \\
\hline $\begin{array}{c}\text { Graphic } \\
\text { Organizer }\end{array}$ & 72 & 46.18 & 12.13 & 60.86 & $\begin{array}{c}10.0 \\
8\end{array}$ & 14.68 & 2nd \\
\hline Animation & 74 & 44.35 & 8.693 & 64.95 & $\begin{array}{c}8.84 \\
4\end{array}$ & 20.60 & 1 st \\
\hline $\begin{array}{c}\text { Conventio } \\
\text { nal }\end{array}$ & 81 & 47.40 & 9.947 & 51.21 & $\begin{array}{c}9.74 \\
9\end{array}$ & 3.81 & 3rd \\
\hline
\end{tabular}

Table 1 showed that the students exposed to graphic organizer, animation and conventional strategies had mean scores of $46.18,44.35$ and 47.40 respectively prior treatment. On exposure to treatment, the experimental groups were exposed to graphic organizer and animation strategies with animation strategy having the highest mean score of 64.95 , closely followed by graphic organizer of mean score of 60.86 , and while the students taught conventionally had the least mean score of 51.21. By implication, the use of animation strategy appears to be the most effective, followed by the graphic organizer and conventional method.

Research Question 2: What is the effect of graphic organizer and animation on the attitude of students in Mathematics?

Table 2: Attitude of students before and after exposure to of graphic organizer and animation

\begin{tabular}{|c|c|c|c|c|c|c|c|}
\hline \multirow{2}{*}{ Methods } & \multirow{2}{*}{$\mathrm{N}$} & \multicolumn{2}{|c|}{ Pretest } & \multicolumn{2}{c|}{ Posttest } & \multirow{2}{*}{$\begin{array}{c}\text { Mean } \\
\text { diff }\end{array}$} & $\begin{array}{c}\text { Relative } \\
\text { performance }\end{array}$ \\
\cline { 3 - 7 } & & Mean & SD & Mean & SD & & \\
\hline $\begin{array}{c}\text { Graphic } \\
\text { Organizer }\end{array}$ & 72 & 18.25 & 2.06 & 30.14 & 6.03 & 11.89 & 1 st \\
\hline Animation & 74 & 18.55 & 2.47 & 28.16 & 5.59 & 9.61 & 2nd \\
\hline Conventional & 81 & 18.24 & 2.10 & 23.02 & 1.96 & 4.78 & 3rd \\
\hline
\end{tabular}

Table 2 showed that the students attitude exposed to graphic organizer, animation and conventional strategies had attitudinal mean scores of 18.25, 18.55 and 18.24 respectively prior treatment. On exposure to treatment, the experimental groups were exposed to graphic organizer and animation strategies with graphic organizer strategy having the highest attitudinal mean score of 30.14 , closely followed by animation strategy of attitudinal mean score of 28.16 while the students taught conventionally had the least attitudinal mean score of 23.02. By implication, the use of graphic organizer strategy appears to be the most effective in attitudinal changes, followed by the animation strategy and conventional method.

\section{Research Hypotheses}

1. There is no significant difference in the mean score of students in the experimental and control groups prior treatment

Table 3: ANOVA Summary on student's performance in the experimental and control groups prior treatment

\begin{tabular}{|c|c|c|c|c|c|}
\hline Source & SS & Df & MS & F & P \\
\hline Between groups & 361.054 & 2 & 180.527 & & \\
\cline { 1 - 4 } Within groups & 23892.876 & 224 & 106.665 & \multirow{2}{*}{1.692} & 0.186 \\
\cline { 1 - 4 } Total & 24253.930 & 226 & & & \\
\hline
\end{tabular}

Table 3 showed that $\mathrm{F}_{2,224}=1.692, \mathrm{P}>0.05$. Which means that there is no significant difference in the mean score of students in the experimental and control groups prior treatment? Hence, the null hypothesis was not rejected. This implies that the two experimental groups and the conventional group were homogenous at the beginning of the experiment, and any change in the performance could be as a result of other impetus that may be put in place.

2. There is no significant difference in the mean score of students in the experimental and control groups after treatment

Table 4: ANOVA Summary on student's performance in the experimental and control groups after treatment

\begin{tabular}{|c|c|c|c|c|c|}
\hline Source & SS & Df & MS & F & P \\
\hline Between groups & 7766.860 & 2 & 3883.430 & & \\
\cline { 1 - 4 } Within groups & 20507.827 & 224 & 91.553 & \multirow{2}{*}{$42.417 *$} & .000 \\
\cline { 1 - 4 } Total & 28274.678 & 226 & & & \\
\hline
\end{tabular}

Table 4 showed that $\mathrm{F}_{2,224}=42.417, \mathrm{P}<0.05$. which means that there is significant difference in the mean score of students exposed to graphic organizer and animation and control groups after treatment. Hence, the null hypothesis was rejected. In order to locate the sources of pair wise significant difference among the groups, Scheffe post-hoc analysis was carried out. The result is presented in Table 4

Table 5: Scheffe Post-Hoc Analysis of students Performance in experimental and control after treatment

\begin{tabular}{|c|c|c|c|c|c|}
\hline Group & (GO) & A & C & N & Mean \\
\hline $\begin{array}{c}\text { Graphic organizer } \\
\text { (GO) }\end{array}$ & & $*$ & $*$ & 74 & 64.95 \\
\hline Animation (A) & & & $*$ & 72 & 60.86 \\
\hline Conventional (C) & & & & 81 & 51.21 \\
\hline
\end{tabular}

Table 5 showed that there is a significant difference between the performance of students exposed to graphic organizer and animation strategies. Similarly, there is a significant difference between the performance of students exposed to graphic organizer and conventional groups. Also, there is a significant difference between the performance of students exposed to animation and conventional strategies, all at 0.05 level of significance. 
3. There is no significant difference in the attitudinal mean score of students in the experimental and control groups before treatment

Table 6: ANOVASummary on the attitudinal mean score of students in the experimental and control groups before treatment

\begin{tabular}{|c|c|c|c|c|c|}
\hline Source & SS & Df & $\begin{array}{c}\text { Mean } \\
\text { square }\end{array}$ & F & Sig. \\
\cline { 1 - 4 } $\begin{array}{c}\text { Between } \\
\text { groups }\end{array}$ & 1075.504 & 2 & 537.752 & & \\
\cline { 1 - 4 } $\begin{array}{c}\text { Within } \\
\text { groups }\end{array}$ & 38065.296 & 224 & 494.354 & \multirow{2}{*}{1.088} & 0.342 \\
\cline { 1 - 4 } Total & 39140.800 & 226 & & \\
\hline
\end{tabular}

Table 6 showed that $\mathrm{F}_{2,224}=1.088, \mathrm{P}>0.05$. Which means that there is no significant difference in the attitudinal mean score of students in the experimental and control groups prior treatment? Hence, the null hypothesis was not rejected. This implies that the two experimental groups and the conventional group were homogenous at the beginning of the experiment, and any change in the attitude could be as a result of any treatment that may be put in place.

4. There is no significant difference in the attitudinal mean score of students in the experimental and control groups after treatment

Table 7: ANOVA Summary on the attitudinal mean score of students in the experimental and control groups after treatment

\begin{tabular}{|c|c|c|c|c|c|}
\hline Source & SS & Df & $\begin{array}{c}\text { Mean } \\
\text { square }\end{array}$ & F & Sig. \\
\hline $\begin{array}{c}\text { Between } \\
\text { groups }\end{array}$ & 9170.725 & 2 & 4585.362 & & \\
\cline { 1 - 4 } $\begin{array}{c}\text { Within } \\
\text { groups }\end{array}$ & 99734.823 & 224 & 422.605 & $10.850 *$ & .000 \\
\cline { 1 - 4 } Total & 108905.548 & 226 & & & \\
\hline
\end{tabular}

Table 7 showed that $F_{2,224}=10.850, P<0.05$. which means that there is significant difference in the attitudinal mean score of students in the experimental and control groups after treatment. Hence, the null hypothesis was rejected. In order to locate the sources of attitudinal pair wise significant difference among the groups, Scheffe post-hoc analysis was carried out. The result is presented in Table 7

Table 8: Scheffe Post-Hoc Analysis of students Attitude in experimental and control after treatment

\begin{tabular}{|c|c|c|c|c|c|}
\hline Group & (GO) & A & C & N & Mean \\
\hline $\begin{array}{c}\text { Graphic organizer } \\
\text { (GO) }\end{array}$ & & & $*$ & 74 & 64.95 \\
\hline Animation (A) & & & $*$ & 72 & 60.86 \\
\hline Conventional (C) & & & & 81 & 51.21 \\
\hline
\end{tabular}

Table 8 showed that there is a significant difference between the attitude of students exposed to graphic organizer and conventional strategies. Similarly, there is a significant difference between the attitude of students exposed to animation and conventional groups, all at 0.05 level of significance.

\section{DISCUSSION}

The findings of the study revealed that that there is significant difference in the mean score of students exposed to graphic organizer and animation and control groups after treatment. This result is in agreement with the study conducted by Stowe (2015) that graphic organizers are meant to help students clearly visualize how ideas are organized within a text or surrounding a concept. The study also supported the work of Owolabi and Oginni (2014) that the students that were taught with animation teaching outperformed the students that were exposed to the traditional method of teaching.

The findings of the study equally revealed that there is a significant difference between the performance of students exposed to graphic organizer and animation strategies in favour of animation strategies. This is concordance with the work of Taylor, Pountney and Malabar (2007) who found out that animated learning materials can prove more useful than static representations for some topics in an experiment conducted with a group of UK undergraduate.

The findings also revealed that there is significant difference in the attitudinal mean score of students in the graphic organizer, animation and conventional strategies in favor of graphic organizer. This implies that the use of graphic organizer has a positive turnaround in the attitudinal change of students in Mathematics than other strategies. This result corroborated McElory \& Coughlin, (2009) that graphic organizer enhanced the critical thinking and higher order thinking skills of the students. Based on the findings of this study, the use of graphic organizer and animation strategies enhance better performance in Mathematics.

\section{CONCLUSION}

Graphic organizers and animation strategies have broad applications in secondary school mathematics instruction. They can be used to facilitate instruction of complex procedures, such as the solving of systems of equations. Anecdotal evidence from the study supports classroom experience that the students' attitude become positively affected when graphic organizer was applied and best performance of students was amplified when animation strategy was employed. Further research could investigate the effectiveness of graphic organizers and animation applied to other higher-level mathematics content, as well as pursuing efforts to train teachers to use graphic organizers and animation.

\section{REFERENCES}

[1] Delinda V. G. (2007). Teaching Students with LD to Solve Mathematical Word Problems. Journal of Learning Disabilities, 40(6), 540-553.

[2] Justice E., Osei K.A and Daniel N. (2015) Factors Influencing Students' Mathematics Performance in Some Selected Colleges of Education in Ghana. International Journal Of Education Learning and Development 3 (3) .68-74

[3] Kumar, M. \&Rizwaan, M. (2013). Impact of Teaching through Concept mapping on Achievement in Social Studies' Components. International Indexed \& Refereed Research Journal. 4(46). 54-57. 
[4] Owolabi J, and Adaramati, T.F.(2015) Effects of Graphic Organiser on Students' Achievement in Algebraic Word ProblemsJournal of Education and Practice 6 (5) 39-44

[5] Owolabi, O.T. and Oginni, O.I. (2014). Effectiveness of animation and multimedia teaching on students' performance in science subjects. British Journal of Education, Society \&Behavioural Science. 4 (2) 201-210.
[6] Stowe, M. (2015) Graphic Organizers: Guiding Principles and Effective Practices. Training \& Technical Assistance Center, Williamsburg.

[7] Taylor M, Pountney D and Malabar I. (2007) Animation as an aid for the teaching of mathematical concepts, Journal of Further and Higher Education 31(3):249-261

[8] Végh L, and Stoffová, V. (2017) Algorithm Animations for Teaching and Learning the Main Ideas of Basic Sortings. Informatics in Education, 16 (1) 121-140. 